\title{
PERBEDAAN PERILAKU BELANJA ANTARA MAHASISWA DAN MAHASISWI DI STAH NEGERI GDE PUDJA MATARAM
}

\author{
Nengah Sukendri ${ }^{1)}$ \\ ${ }^{1}$ STAHN Gde Pudja Mataram,
}

\begin{abstract}
ABSTRAK
Penelitian ini bertujuan untuk menganalisis perbedaan perilaku belanja antara mahasiswa dan mahasiswi di lingkungan Sekolah Tinggi Agama Hindu Negeri Gde Pudja Mataram. Melalui penggunaan jenis penelitian komparatif dan alat analisis yang digunakan berupa uji-t 2 sampel independen untuk mengetahui perilaku belanja diantara mahasiswa dan mahasiswi tersebut. Hasil Penelitian Menunjukan bahwa ada perbedaan diantara mahasiswa dan mahasiswi dan perbedaan tersebut menunjukan bahwa mahasiswi memiliki perilaku belanja yang lebih besar dari pada mahasiswa
\end{abstract}

Kata Kunci: Perilaku Belanja, Pengeluaran, Mahasiswa dan Mahasiswi

\begin{abstract}
This study aims to to analyze difference Shopping behavior between male students and female students at College of Hinduism Gde Pudja Mataram. With comparative design and an instrument of analysis that was used 2 sample independent t-test, in order to analyze difference Shopping behavior between male students and female students. The results of the study showed that there was some differences between male students and female student and thats difference caused female student having shopping behavior greater than male student.
\end{abstract}

Key Word: Shopping Behavior, Expenditure, Male Student and Female Student

\section{PENDAHULUAN}

Manusia memiliki kebutuhan hidup yang dipenuhi dengan cara yang berbedabeda. Ada yang memenuhi kebutuhannya dalam batas kenormalan, ada juga yang berlebihan dalam pemenuhan kebutuhannya dan bahkan ada yang sangat ekstrim. Perilaku konsumtif merupakan kegiatan manusia untuk pemenuhan kebutuhan diatas ambang batas kewajaran dan kegiatan pemenuhan kebutuhan yang tergolong ekstrim. Hal yang demikian itu terjadi pada hampir semua lapisan masyarakat. Perilaku konsumtif tidak hanya pada orang dewasa, perilaku konsumtif pun banyak melanda para remaja. Remaja dan orang yang beranjak dewasa memang sering dijadikan target pemasaran berbagai produk industri, antara lain karena karakteristik mereka yang labil, spesifik dan mudah dipengaruhi sehingga akhirnya mendorong munculnya berbagai gejala dalam perilaku membeli yang tidak wajar. Membeli tidak lagi dilakukan karena produk tersebut memang dibutuhkan, namun membeli dilakukan karena alasan-alasan lain seperti sekedar mengikuti perkembangan, hanya ingin mencoba produk baru, ingin memperoleh pengakuan sosial, prestise dan sebagainya.

Para remaja dan orang yang beranjak dewasa merupakan obyek yang menarik untuk diminati oleh para ahli pemasaran. Kelompok usia tersebut tergolong dalam salah satu pasar yang potensial bagi produsen karena remaja biasanya mudah terbujuk rayuan 
iklan, suka ikut-ikutan teman, tidak realistis, dan cenderung boros dalam menggunakan uangnya, lebih mudah terpengaruh teman sebaya dalam hal berperilaku dan biasanya lebih mementingkan gengsinya untuk membeli barang-barang bermerk agar mereka dianggap tidak ketinggalan zaman.

Perilaku konsumtif remaja dan orang bernajak dewasa tersebut dapat diamati pada mahasiswa yang sebenarnya belum memiliki kemampuan finansial untuk memenuhi kebutuhannya. Menurut Chita dkk. (2015) adanya self-control pada remaja merupakan kapasitas dalam diri yang dapat digunakan untuk mengontrol variabelvariabel luar yang menentukan tingkah laku.Kondisi emosi remaja yang tidak stabil membuat remaja menjadi konsumtif. Perilaku konsumtif remaja pada produk fashion adalah untuk mendukung presentasi mereka. Perilaku konsumtif yang terjadi juga lebih dimudahkan dengan adanya Online Shopping.

Penelitan Abdilah (2017) yang membuktikan bahwa adanya pengaruh langsung kecenderungan neurotisisme, materialisme, dan orientasi pada fashion terhadap pembelian kompulsif dan pengaruh tidak langsung terhadap pembelian kompulsif melalui materialisme dan orientasi fashion. Dengan demikian materialisme dan orientasi terhadap fashion memperkuat kecenderungan neurotisisme terhadap perilaku pembelian kompulsif. Menurut Aprilia dan Hartoyo (2014) Mahasiswa yang berperilaku konsumtif mengalami perubahan pola hidup, dimana terdapat batas yang bias antara kebutuhan pokok dan kebutuhan tersier. Kebutuhan mahasiswa kian hari semakin berubah mengakibatkan mahasiswa kurang cermat dalam mengatur keuangan yaitu bukan berdasarkan skala prioritas, dan lebih cenderung dipengaruhi oleh kondisi lingkungannya. Hal tersebut menimbulkan dilema, antara pemenuhan kebutuhan pokok yang pada kenyataanya lebih penting dengan pemenuhan kebutuhan gaya hidup untuk memenuhi simbol yang dapat diterima oleh lingkungan. Mahasiswa yang berasal dari keluarga yang mampu, dalam pemenuhan kebutuhan hidupnya tidak akan menjadi masalah dalam perilaku konsumtif ini, namun lain hal nya apabila orang tua mahasiswa tersebut berpenghasilan cukup. Melihat kecendrungan tersebut maka pengamatan terhadap perilaku belanja terhadap mahasiswa merupakan sebuah hal yang menarik.

Lebih Spesifik lagi penelitian Miranti (2012) yang meneliti perbedaan jenis kelamin terhadap pembelian produk yang ramah lingkungan. Hasil penelitian tersebut menyebutkan bahwa terdapat perbedaan rata-rata antara laki-laki dan perempuan pada semua variabel yang diteliti dimana secara umum konsumen perempuan yang ditunjukkan dengan adanya pemikiran, perilaku dan emosi yang lebih besar terkait dengan perlindungan lingkungan. Namun dalam pengaruh sesama teman ditemukan bahwa konsumen laki-laki lebih terpengaruh dari konsumen perempuan. Melihat hasil yang ambigu pada penelitian Miranda (2012) tersebut maka dilakukan penelitian dengan objek yang berbeda yaitu pada mahasiswa dan mahasiswi. Penelitian ini dilakukan di Sekolah Tinggi Agama Hindu Negeri Gde Pudja Mataram (STAHN Gde Pudja Mataram) yang saat ini memiliki jumlah mahasiswa 290 orang. Berikut gambaran jumlah mahasiswa dan mahasiswi yang ada di STAHN Gde Pudja Mataram.

Tabel 1, Jumlah Mahasiswa dan Mahasiswi di STAHN Gde Pudja Mataram Tahun 2017

\begin{tabular}{|c|l|l|}
\hline No & \multicolumn{1}{|c|}{ Jenis Kelamin } & \multicolumn{1}{c|}{ Jumlah (orang) } \\
\hline 1. & Laki-laki (Mahasiswa) & 138 \\
\hline 2. & Perempuan (Mahasiswi) & 152 \\
\hline & \multicolumn{1}{|c|}{ Total } & 290 \\
\hline
\end{tabular}

Sumber: Data Sekunder (diolah) 
Pada tabel 1 tersebut menunjukan jumlah mahasiswi lebih banyak dibandingkan dengan jumlah mahasiswa. Namun demikian selisih antara keduanya tidak terlampau besar, hanya 14 orang. Selain itu penelitian ini dimotivasi terkait dengan penelitian Sari (2015) yang menunjukan bahwa mahasiswi memiliki perilaku belanja konsumtif yang sangat tinggi. Dengan demikian perlu kiranya dilakukan penelitian dengan judul "perbedaan perilaku belanja antara mahasiswa dan mahasiswi di STAH Negeri Gde Pudja Mataram".

\section{RUMUSAN MASALAH}

Berdasarkan fenomena yang yang muncul dari beberapa penilitaian terdahulu dan jumlah mahasiswa yang tidak terlalu jauh perbedaannya, maka dirumuskan masalah yaitu: Apakah ada perbedaan perilaku belanja antara mahasiswa dan mahasiswi di STAHN Gde Pudja Mataram?

\section{TUJUAN}

Berdasarkan masalah rumusan masalah yang telah disampaikan sebelumnya maka tujuan penelitian ini adalah untuk menganalisis perbedaan perilaku belanja antara mahasiswa dan mahasiswi di lingkungan Sekolah Tinggi Agama Hindu Negeri Gde Pudja Mataram.

\section{KERANGKA TEORITIS, DAN HIPOTESIS PERILAKU KONSUMTIF}

Mangkunegara (2002:3) menyampaikan bahwa perilaku konsumtif dapat didefinisikan sebagai tindakan-tindakan individu yang secara langsung terlibat dalam usaha memperoleh dan menggunakan barang-barang jasa ekonomis termasuk proses pengambilan keputusan yang mendahului dan menentukan tindakan-tindakan tersebut. Perilaku konsumtif bisa dilakukan oleh siapa saja.

Pendapat tersebut mengartikan bahwa perilaku membeli yang berlebihan tidak lagi mencerminkan usaha manusia untuk memanfaatkan uang secara ekonomis, namun perilaku konsumtif dijadikan sebagai suatu sarana untuk menghadirkan diri dengan cara yang kurang tepat. Perilaku tersebut menggambarkan sesuatu yang tidak rasional dan bersifat kompulsif sehingga secara ekonomis menimbulkan pemborosan dan inefisiensi biaya. Sedangkan secara psikologis menimbulkan kecemasan dan rasa tidak aman.Konsumen dalam membeli suatu produk bukan lagi untuk memenuhi kebutuhan semata-mata, tetapi juga keinginan untuk memuaskan kesenangan. Keinginan tersebut seringkali mendorong seseorang untuk membeli barang yang sebenarnya tidak dibutuhkan. Hal ini dapat dilihat dari pembelian produk oleh konsumen yang bukan lagi untuk memenuhi kebutuhan semata tetapi juga keinginan untuk meniru orang lain yaitu agar mereka tidak berbeda dengan anggota kelompoknya atau bahkan untuk menjaga gengsi agar tidak ketinggalan jaman. Keputusan pembelian yang didominasi oleh faktor emosi menyebabkan timbulnya perilaku konsumtif. Hal ini dapat dibuktikan dalam 
perilaku konsumtif yaitu perilaku membeli sesuatu yang belum tentu menjadi kebutuhannya serta bukan menjadi prioritas utama dan menimbulkan pemborosan.

Kognisi konsumen biasanya melibatkan pikiran, ditandai dengan pemilihan atau seleksi dari informasi kualitas, kuantitas, harga, kebutuhan, dan dapat terjadi melalui proses berpikir sadar maupun tidak sadar serta secara otomatis langsung tertarik untuk membeli. Menurut Zaltman dan Wallendorf (1971), motif-motif kognitif menekankan pada proses informasi seseorang. Macam-macam motif kognitif Konsistensi, Atribut, Motif, Kategorisasi, Objektifitas, Autonomi, Stimulasi, Teologis, danUtilitarian,

Proses kognisi yang dilalui konsumen, dimulai dari semua stimulus diterima hingga stimulus tersebut dimasukan ke dalam memory dan dapat dipergunakan kembali untuk memberikan gambaran/persepsi yang lebih baik mengenai suatu produk/jasa kepada konsumen (Dwiastuti dkk., 2012). Bagian ini lebih lanjut akan dibahas lebih rinci mengenai tahapan proses informasi mulai dari pemaparan, perhatian, pemahaman, penerimaan dan retensi.

Afeksi dan kognisi adalah bentuk tanggapan psikologis lainnya yang dapat muncul dalam situasi seperti ketika berbelanja bahan pangan (Dwiastuti dkk. (2012). Afeksi mengacu pada tanggapan perasaan sedangkan kognisi lebih pada tanggapan mental atau pemikiran. Lebih jelasnya afeksi adalah keberadaan seseorang atau sesuatu yang dirasakan seseorang (senang, marah, bosan). Orang dapat mengalami empat jenis tanggapan afektif : emosi, perasaan tertentu, suasana hati dan evaluasi. Faktor Eksternal/Lingkungan. Perilaku konsumtif dipengaruhi oleh lingkungan di mana ia dilahirkan dan dibesarkan. Variabel-variabel yang termasuk dalam faktor eksternal dan mempengaruhi perilaku konsumtif adalah kebudayaan, kelas sosial, kelompok sosial, dan keluarga.

Lingkungan (environment) mengacu pada rangsangan fisik dan sosial yang kompleks di dunia eksternal konsumen. Termasuk didalamnya benda-benda, tempat, dan orang lain yang mempengaruhi afeksi dan kognisi konsumen serta perilakunya. Bagian penting dari lingkungan adalah rangsangan fisik dan sosial yang diciptakan oleh pemasar untuk mempengaruhi konsumen. Lingkungan sosial adalah semua interaksi sosial yang terjadi antara konsumen dengan orang sekelilingnya atau antara banyak orang. Lingkungan sosial adalah orang-orang lain yang berada di sekeliling konsumen dan termasuk perilaku dari orang-orang tersebut. Lingkungan fisik adalah segala sesuatu yang berbentuk fisik di sekeliling konsumen. Yang termasuk lingkungan fisik adalah beragam produk, toko, lokasi toko, dan lain-lain. Contoh : rumah adalah lingkungan mikro fisik dari konsumen, karena akan mempengaruhi sikap dan perilaku secara langsung (Sumarwan, 2003).

Upaya Bimbingan dan Konseling dalam Menanggulangi Masalah Perilaku Konsumtif Perilaku konsumtif remaja terhadap barang-barang bermerk banyak tumbuh pada remaja yang besar dan tumbuh di kota-kota besar sehingga mereka menjadikan mall sebagai rumah keduanya. Seperti contoh kasus di atas. Salah satu alasanya, mereka ingin menunjukkan diri bahwa mereka juga dapat mengikuti mode yang sedang beredar. Padahal mode itu sendiri selalu berubah, sehingga para remaja tidak pernah puas dengan apa yang dimilikinya. Dalam peniruan ini. Hal ini menyebabkan banyak orang tua yang mengeluh saat anaknya mulai memasuki dunia remaja. Salah satu penyebab timbulnya keluhan orangtua, karena sebagian perilaku remaja menimbulkan masalah ekonomi pada keluarganya. Dengan banyaknya dampak negatif akibat perilaku konsumtif ini, maka upaya bimbingan dan konseling diperlukan dalam menanggulangi perilaku konsumtif. Bimbingan dan konseling dapat melakukan upaya kuratif, karena apabila 
perilaku konsumtif tersebut dibiarkan maka akan terus mengakar di dalam gaya hidup dan akan berlanjut sampai dewasa. Dampak negatif akan lebih besar terjadi apabila pencapaian finansial didapatkan melalui segala macam cara yang tidak sehat. Teknik yang digunakan adalah konseling individual melalui interaksi yang berkelanjutan antara konselor dan konseli sehingga mengkontrol dirinya dan perilaku konsumtif remaja tersebut dapat disembuhkan. Walaupun beberapa penelitian terdahulu hasilnya masih mengalami kontroversi maka dapat disusun kerangka konseptual sebagai berikut:

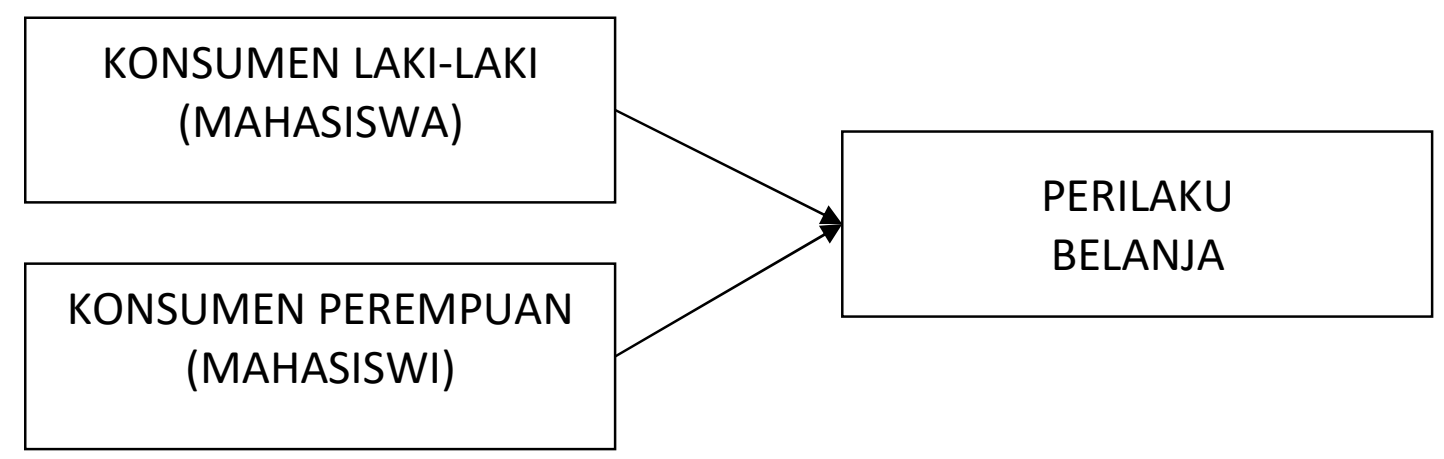

Gambar 1. Kerangka Konseptual

Berdasarkan pada Gambar 1 tersebut maka dapat disusun hipotesis penelitian sebagai berikut:

H1 : Terdapat Perbedaan Perilaku Belanja diantara Mahasiswa dan Mahasiswi STAHN Gde Pudja Mataram

\section{METODE PENELITIAN}

\section{Jenis Penelitian}

Penelitian ini merupakan penelitian kuantitatif dengan jenis penelitian komparatif yang membandingkan antara perilaku belanja mahasiswa dan perilaku belanja mahasiswi. Hasil komparasi secara statistik ini diharapkan menjawab keambiguan hasil penelitian terdahulu terkait dengan pola perilaku belanja.

\section{Lokasi Penelitian}

Penelitian ini dilakukan mahasiswa dan mahasiswi yang aktif mengikuti perkuliahan di Sekolah Tinggi Agama Hindu Gde Pudja Mataram.

\section{Jenis Data}

Jenis data yang digunakan dalam penelitian ini adalah data sekunder dan data primer. Data sekunder yang merupakan data yang diperoleh dari STAHN Gde Pudja Mataram, misalnya jumlah mahasiswa. Data primer merupakan data yang diperoleh langsung dilapangan tanpa melalui perantara, contohnya data pengumpulan kuesioner pada mahasiswa dan mahasiswi. 


\section{TEKNIK PENGUMPULAN DATA}

Teknik pengumpulan data yang yang digunakan dalam penelitian ini adalah dokumentasi, yang dilakukan dengan mencatat data sekunder terutama laporan keuangan perusahaan selama penelitian berlangsung. Selain itu dilakukan teknik angket atau kuesioner dengan melakukan pembagian kuesioner untuk diisi oleh mahasiswa dan mahasiswi.

\section{UJI INSTRUMEN PENELITIAN}

Penelitian kuantitatif dalam riset ini menggunakan data dari pengumpulan melalui kusioner, namun sebelum diolah dengan uji-t, maka harus dilakukan uji dasar yang dibutuhkan, yaitu uji normalitas data.

\section{POPULASI DAN SAMPEL PENELITIAN}

Populasi dalam penelitian adalah seluruh Mahasiswa dan mahasiswi yang terdaftar sebagai mahasiswa aktif di Sekolah Tinggi Agama Hindu Gde Pudja Mataram pada tahun ajaran 2017/2018.Setelah itu diambil sampel dengan menggunakan salah satu metode dari metode penentuan sampel probability sample (sampel probabilitas) yaitu menggunakan accidental sampling. Teknik accidental sampling merupakan teknik pengambilan sampel pada elemen populasi yang dapat ditemui dan bersedia untuk menberikan informasi terkait dengan data pada penelitian.

\section{PROSEDUR ANALISIS DATA}

Upaya dalam menjawab rumusan masalah dan tujuan penelitian maka digunakan uji beda yang menggunakan analisis uji t (t-test) dua sampel Independen (independent $t$ test), yang digunakan dalam membandingkan faktor karakter yang dominan antara mahasiswa dan mahasiswi. Uji $\mathrm{t}$ dua sampel ini tergolong uji perbandingan (komparatif). Menurut Riduwan (2011), uji kedua ini gunanya untuk menguji kemampuan generalisasi (signifikansi hasil penelitian) yang berupa perbandingan keadaan variabel dari dua rata-rata sampel.

Rumus uji t dua sampel:

$$
t_{h i t}=\frac{\overline{X_{1}}-\overline{X_{2}}}{\sqrt{\frac{S_{1}^{2}}{n_{1}}+\frac{S_{2}^{2}}{n_{2}}-2 r\left(\frac{S_{1}}{\sqrt{n_{1}}}\right)+\left(\frac{S_{2}}{\sqrt{n_{2}}}\right)}}
$$

$$
\begin{array}{ll}
\text { Keterangan: } & \\
\mathrm{r} & =\text { Nilai korelasi karakter Siswa dengan karakter siswi } \\
\frac{\mathrm{n} 1 \text { dan } \mathrm{n} 2}{X_{1}} & =\text { Jumlah sampel } \\
\frac{X_{2}}{S_{1}} & =\text { Rata-rata sampel ke-1 } \\
& =\text { Rata-rata sampel ke-2 } \\
& =\text { Standar Deviasi sampel ke-1 }
\end{array}
$$

78 | Perbedaan Perilaku Belanja Antara Mahasiswa Dan... 


$$
\begin{array}{ll}
S_{2} & =\text { Standar Deviasi sampel ke-2 } \\
S_{1}{ }^{2} & =\text { Varians sampel ke-1 } \\
S_{2}{ }^{2} & =\text { Varians sampel ke-2 }
\end{array}
$$

Dalam penelitian ini menggunakan SPSS 22.00. Kriteria pengujian uji t dua sampel dalam SPSS menurut Yamin (2009) adalah nilai $\rho$ value atau nilai signifikansi statistik thitung $<$ dari 0,05 berarti ada perbedaan yang signifikan karakter ditinjau dari sudut pandang gender.

\section{ANALISIS DATA}

Sebelum melakukan analisis lebih jauh dan mendalam mengenai perbedaan pola belanja mahasiswa dan mahasiswi maka dilakukan uji analisis statistik deskriptif dalam rangka mengetahui karakteristik data yang diolah. Berikut ini satististik deskriptif daridata yang dianalisis.

Tabel 2. Statistik Deskriptif

\begin{tabular}{|l|l|r|r|r|r|}
\hline & \multicolumn{1}{|c|}{ GENDER } & N & \multicolumn{1}{c|}{ Mean } & Std. Deviation & \multicolumn{1}{c|}{ Std. Error Mean } \\
\hline \multirow{2}{*}{ Dalam Rp. } & MAHASISWA & 10 & 315000,00 & 182650,243 & 57759,078 \\
\cline { 2 - 6 } & MAHASISWI & 8 & 737500,00 & 250356,888 & 88514,527 \\
\hline
\end{tabular}

Pada Tabel 2 tersebut dapat dilihat bahwa terdapat 18 orang yang menjadi responden penelitian yang terdiri dari 10 orang mahasiswa dan 8 orang mahasiswi. Rata-rata pengeluaran mahasiswa selama satu bulan adalah Rp. 315.000,- dan pada mahasiswi memiliki rata-rata pengeluaran lebih besar yaitu sebesar Rp. 737.500,-., sehingga standar deviasi atau penyebaran data untuk mahasiswi juga lebih besar dibandingkan dengan mahasiswa. Terkait dengan data dalam Tabel 2 tersebut maka sementara secara absolut ada perbedaan antara mahasiswa dan mahasiswi, namun hal tersebut harus dibuktukan dengan dangan statistik induktif.

Sebelum dilakukan uji Beda maka yang harus dilakukan adalah melakukan uji normalitas, menggunakan uji kolmogorov smirnov yang dikonfirmasi dengan metode grafik (Putra;2007). Uji normalitas ini merupakan uji satu sampel kolmogorov-smirnov yang tergolong jenis uji non parametrik. Tabel berikut ini adalah merupakan hasil uji normalitas menggunakn metode kolmogorov smirnov.

Tabel 3. Hasil Uji Kolmogorov Smirnov

\begin{tabular}{|l|l|r|}
\hline \multicolumn{2}{|l|}{} & \multicolumn{1}{c|}{ Dalam Rp. } \\
\hline $\mathrm{N}$ & Mean & 18 \\
\cline { 2 - 3 } Normal Parameters ${ }^{\mathrm{a}, \mathrm{b}}$ & Std. Deviation & 502777,78 \\
\hline \multirow{2}{*}{ Most Extreme Differences } & Absolute & 300231,392 \\
\cline { 2 - 3 } & Positive &, 170 \\
\cline { 2 - 3 } & Negative &, 170 \\
\hline \multicolumn{2}{|l|}{} &,- 118 \\
\hline Test Statistic &, 170 \\
\hline Asymp. Sig. (2-tailed) &, 179 \\
\hline
\end{tabular}

Sumber: data diolah 
Menurut Tabel 3. Terlihat bahwa nilai signifikansi kolmogorov-smirnov data yang dianalisis menunjukan nilai 0,179 . Angka tersebut ternyata jauh lebih besar dari tingkat kesalahan 0,05, maka bisa dipastikan bahwa data yang diolah berdistribusi normal. Dalam memastikan bahwa data yang diolah telah berdistrubusi normal, maka digunakan pula metode gfik dengan menggunakan normal p-p plot sebagai berikut:

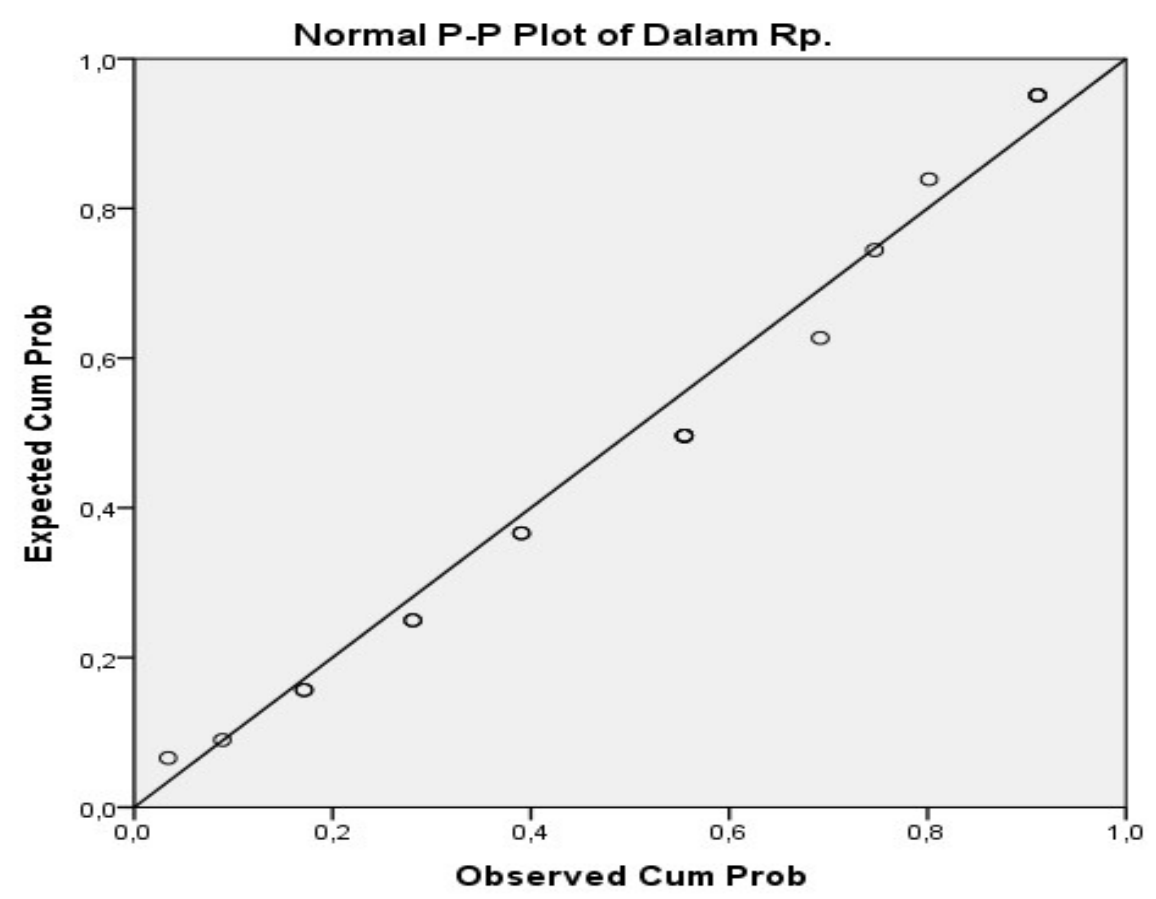

Gambar 2. Normal P-P Plot

Grafik yang terpampang pada Gambar 2 tersebut menunjukan bahwa data yang diolah dalam penelitian tersebar berupa titik-titik sepanjang garis diaginal yang melintang dari bawah keatas. Terlihat titik-titik tersebut tersebar secara teratur sepanjang garis diagonal yang mengindikasikan bahwa data yang diolah dalam penelitian ini telah memiliki atau memenuhi distribusi normal.

Selanjutnya baru dilakukan uji beda dengan menggunakan uji $t$ dua sampel independent (t-test Independent 2 sample ). Hasil uji t-test independen 2 sample menunjukan perbandingan antara penegeluaran mahasiswa dengan mahasiswi sebagai berikut:

Tabel 4. Uji Beda 2 Sampel Independen

\begin{tabular}{|c|c|c|c|c|c|c|c|c|c|c|}
\hline \multicolumn{11}{|c|}{ Independent Samples Test } \\
\hline & & $\begin{array}{r}\text { Lever } \\
\text { Test } \\
\text { Equali } \\
\text { Variar }\end{array}$ & $\begin{array}{l}\text { e's } \\
\text { for } \\
y \text { of } \\
\text { cees }\end{array}$ & \multicolumn{7}{|c|}{ t-test for Equality of Means } \\
\hline & & \multirow[t]{2}{*}{$\mathrm{F}$} & \multirow[t]{2}{*}{ Sig } & \multirow[t]{2}{*}{$\mathrm{T}$} & \multirow[t]{2}{*}{ Df } & \multirow{2}{*}{$\begin{array}{l}\text { Sig. (2- } \\
\text { tailed) }\end{array}$} & \multirow{2}{*}{$\begin{array}{c}\text { Mean } \\
\text { Difference }\end{array}$} & \multirow{2}{*}{$\begin{array}{l}\text { Std. Error } \\
\text { Difference }\end{array}$} & \multicolumn{2}{|c|}{$\begin{array}{l}95 \% \text { Confidence Interval of } \\
\text { the Difference }\end{array}$} \\
\hline & & & & & & & & & Lower & Upper \\
\hline $\begin{array}{l}\text { Dalam } \\
\text { Rp. }\end{array}$ & $\begin{array}{l}\text { Equal } \\
\text { variances } \\
\text { assumed }\end{array}$ & 1,864 & $\begin{array}{r}19 \\
1\end{array}$ & $-4,145$ & 16 & ,001 & $-422500,000$ & 101942,079 & $-638607,554$ & $-206392,446$ \\
\hline
\end{tabular}




\begin{tabular}{|c|c|c|c|c|c|c|c|c|c|}
\hline \multicolumn{10}{|c|}{ Independent Samples Test } \\
\hline & $\begin{array}{r}\text { Le } \\
\text { Te } \\
\text { Equi } \\
\text { Var }\end{array}$ & $\begin{array}{l}\text { e's } \\
\text { for } \\
\text { y of } \\
\text { cees }\end{array}$ & \multicolumn{7}{|c|}{ t-test for Equality of Means } \\
\hline & \multirow[t]{2}{*}{$\mathrm{F}$} & \multirow[t]{2}{*}{ Sig } & \multirow[t]{2}{*}{$\mathrm{T}$} & \multirow[t]{2}{*}{$\mathrm{Df}$} & \multirow{2}{*}{$\begin{array}{l}\text { Sig. (2- } \\
\text { tailed) }\end{array}$} & \multirow{2}{*}{$\begin{array}{c}\text { Mean } \\
\text { Difference }\end{array}$} & \multirow{2}{*}{$\begin{array}{l}\text { Std. Error } \\
\text { Difference }\end{array}$} & \multicolumn{2}{|c|}{$\begin{array}{l}95 \% \text { Confidence Interval of } \\
\text { the Difference }\end{array}$} \\
\hline & & & & & & & & Lower & Upper \\
\hline $\begin{array}{l}\text { Equal } \\
\text { variances } \\
\text { not } \\
\text { assumed }\end{array}$ & & & $-3,997$ & $\begin{array}{r}12 \\
472\end{array}$ & ,002 & $-422500,000$ & 105692,632 & $-651822,168$ & $-193177,832$ \\
\hline
\end{tabular}

Berdasarkan uji beda independen 2 sampel tersebut terlihat pada Tabel 4 ada uji homogenitas data, maka sebelumnya harus dilakukan levene test. Levene test merupakan uji homogenitas data, karena sebelum menguji perbedaan lebih jauh harus diketahui apakah data tersebut cenderung heterogen atau sebaliknya homogen (Yamin dan Kurniawan, 2009).

Hasil uji levene-test didapatkan bahwa nilai F-hitung sebesar 1,8464 dan nilai signifikansi sebesar 0,191 yang berarti data memiliki kesamaan variance atau data yang diolah memiliki kecendrungan homogen. Dengan demikian maka dalam melakukan analisis hasil perhitungan yang dipergunakan pada Tabel 4. adalah pada bagian Equal Variance Assumed karena data yang diasumsikan memiliki variasi yang sama (homogen).

Selanjutnya baru dilakukan pengujian perbedaan diantara mahasiswa dan mahasiswi terkait dengan perilaku belanja. Berdasarkan data di Tabel 4. Pada bagian Equal Variance Assumed memiliki t-hitung sebesar -4,145 dan nilai signifikasi sebesar 0,001 yang berarti harus dapat menjawab hipotesis statistik sebagai berikut.

H0 : Tidak ada perbedaan antara mahasiswa dan mahasiswi STAHN Gde Pudja Mataram ditinjau dari perilaku belanjanya.

Ha : Ada perbedaan antara mahasiswa dan mahasiswi STAHN Gde Pudja Mataram ditinjau dari perilaku belanjanya.

Berdasarkan hasil pada Tabel 4. yang nilai signifikansinya memiliki angka lebih kecil dari 0,05 (Putra;2013) atau Sig < 0,05 yaitu sebesar 0,01 , maka harus dilakukan penolakan pada hipotesis nul yang menyatakan bahwa tidak ada perbedaan antara mahasiswa dan mahasiswi ditinjau dari perilaku belanjanya. Dengan demikian hasil ini menerima hipotesis alternatif yang berbunyi ada perbedaan antara mahasiswa dan mahasiswi STAHN Gde Pudja Mataram ditinjau dari perilaku belanja.

\section{PEMBAHASAN}

Hasil pengujian hipotesis statistik tersebut berdampak pada pengujian hipotesis penelitian, yaitu hasil penelitian ini sesuai dengan hipotesis penelitian yang berbunyi ada perbedaan perilaku belanja diantara mahasiswa dan mahasiswi STAHN Gde Pudja Mataram. Perbedaan itu sesuai dengan nilai rata-rata pada statistik deskriptif yang menunjukan pada mahasiswa rata-rata pengeluaran selam sebulan sebesar Rp. 
315.000,- dan untuk mahasiswi rata-ratanya lebih tinggi dua kali lipatnya sebesar Rp. $737.500,-$.

Perbedaan nilai yang cukup signifikan itu disebabkan oleh Faktor Internal. Faktor internal ini juga terdiri dari dua aspek, yaitu faktor psikologis dan faktor pribadi (Tambunan,2001). Faktor psikologis, yaitu faktor kejiwaan dalam bergaya hidup konsumtif. Sikap pendirian dan kepercayaan. Melalui bertindak dan belajar orang akan memperoleh kepercayaan dan pendirian. Dengan kepercayaan pada penjual yang berlebihan dan dengan pendirian yang tidak stabil dapat menyebabkan terjadinya perilaku konsumtif. Selain itu faktor eksternal/Lingkungan. Perilaku konsumtif dipengaruhi oleh lingkungan di mana ia dilahirkan dan dibesarkan. Variabel-variabel yang termasuk dalam faktor eksternal dan mempengaruhi perilaku konsumtif adalah kebudayaan, kelas sosial, kelompok sosial, dan keluarga.

Apalagi saat ini informasi telah mengglobal dengan kemudahan jaringan internet seperti yang disampaikan oleh Sari (2015) Maraknya konsumsi melalui online shop oleh mahasiswa menjadi salah satu latar belakang masalah dalam penelitian ini.Umumnya mahasiswa melakukan belanja online bukan didasarkan pada kebutuhan semata, melainkan demi kesenangan dan gaya hidup sehingga menyebabkan seseorang menjadi boros atau yang yang lebih dikenal dengan istilah perilaku konsumtif atau perilaku konsumerisme. Contohnya jenis kosmetik yang dapat diperoleh misalnya eyeliner, lipstik biasa tanpa glow dan lainnya.Persoalan-persoalan yang sering dihadapi oleh mahasiswi ketika berbelanja online adalah kebanyakan terkait dengan produk yang diterima tidak sesuai dengan gambar yang diposting, lamanya waktu pengiriman, repson yang lambat dari online shop dalam menanggapi order konsumen, dan ongkos kirim yang tergolong mahal.

Pengolahan informasi dan persepsi konsumen adalah salah satu tahapan dalam proses kognisi yang dilalui konsumen, dimulai dari semua stimulus diterima hingga stimulus tersebut dimasukan ke dalam memory dan dapat dipergunakan kembali untuk memberikan gambaran/persepsi yang lebih baik mengenai suatu produk/jasa kepada konsumen (Dwiastuti dkk., 2012;38). Bagian ini lebih lanjut akan dibahas lebih rinci mengenai tahapan proses informasi mulai dari pemaparan, perhatian, pemahaman, penerimaan dan retensi.

Proses informasi tercipta pada saat produsen. memberikan suatu stimulus berupa pemaparan (exposure), bila pemaparan tersebut menarik minat konsumen maka konsumen akan memperhatikan, bila konsumen ingin menafsirkan stimulus tersebut, maka konsumen akan masuk pada tahap pemahaman, dilanjutkan dengan tahap penerimaan dan kemudian retensi. Apa yang didengar oleh telinga, apa yang dilihat oleh mata dan apa yang dicium oleh hidung, itulah yang disebut dengan stimulus. Tidak semua stimulus tersebut semua kita ingat dan simpan dalam ingatan, karena kita sebagai konsumen melakukan proses pengolahan informasi. Stimulus bisa berbentuk produk, nama merk, kemasan, iklan, nama produsen. 


\section{KESIMPULAN}

Berdasarkan hasil dan pembahasan hasil yang telah dilakukan sebelumnya maka dapat disusun kesimpulan sebagai berikut:

1. Ada perbedaan antara perilaku belanja mahasiswa dan mahasiswi di STAHN Gde Pudja Mataram. Perbedaan tersebut tergolong sangat jauh, bahkan lebih dari dua kali lipat nilai pengeluaran mahasiswa dalam sebulannya. Perbedaan tersebut ada berbagai macam penyebabnya yaitu faktor internal dan faktor eksternal.

Faktor internal penyebab dari adanya pengeluaran yang besar dari para mahasiswi adalah faktor psikologis dan kepribadian, dimana perasaan ini berasal dari dalam diri mahasiswi, karena perempuan lebih memiliki rasa ingin terus kelihatan cantik maka dia berusaha untuk memenuhi kebutuhannya untuk mempercantik dirinya dan ada rasa puas ketika hal tersebut tercapai.

Faktor Eksternal penyebab dari adanya pengeluaran dan pola belanja dibentuk oleh lingkungan di mana ia dilahirkan dan dibesarkan. Variabel-variabel yang termasuk dalam faktor eksternal dan mempengaruhi perilaku konsumtif adalah kebudayaan, kelas sosial, kelompok sosial, dan keluarga. Saat ini arus informasi kian mengglobal sehingga semakin mudah untuk mendapat produk dan layanan walau diakses dari rumah sekalipun melalui internet sehingga pengeluaran semakin tinggi khususnya perumpuan untuk mendapatkan make-up, tas, sepatu, baju, celana dan aksesorisnya lainya.

\section{SARAN}

Berdasarkan hasil, pembahasan dan kesimpulan yang telah disampaikan, maka disarankan hal-hal sebagai berikut:

1. Khususnya pada para mahasiswi untuk bisa menahan diri dan memprotek dirinya agar bisa mengendalikan perilaku belanja yang berlebih

2. Melakukan dan menerapkan manajemen keuangan yang lebih ketat lagi, sehingga pengeluaran bisa lebih diatur untuk hal-hal yang lebih bermanfaat lagi dan mengurangi pemborosan.

3. Para mahasiswa yang memiliki kelebihan dana setiap bulannya dapat di tabung atau digunakan untuk hal yang lebih bermanfaat. 


\section{DAFTAR PUSTAKA}

Abdilah, A. 2017. Pengaruh Sifat Psikologis Konsumen Terhadap Pembelian Kompulsif, OPTIMA, Vol. 1, No.2, 32-43

Dwiastuti, R., Shinta, A. dan Isaskar, R 2012. Ilmu Perilaku Konsumen, Universitas Brawijaya Press, Malang

Aprilia, D. dan Hartoyo. 2014. Analisis Sosiologis Perilaku Konsumtif Mahasiswa (Studi Pada Mahasiswa FISIP Universitas Lampung), Sosiologi: Jurnal Ilmiah Kajian Ilmu Sosial dan Budaya, Vol. 15 No. 1, 72-86.

Chita, RCM., David, L. dan Pali, C, 2015. Hubungan Antara Self-Control Dengan Perilaku Konsumtif Online Shopping Produk Fashion Pada Mahasiswa Fakultas Kedokteran Universitas Sam Ratulangi Angkatan 2011, Jurnal e-Biomedik (eBm), Volume 3, Nomor 1, 297-302

Mangkunegara, Anwar Prabu. 2002. Perilaku Konsumen. Bandung : PT. Refika Aditama.

Miranti, S. 2012. Pengaruh Perbedaan Jenis Kelamin Terhadap Perilaku Pembelian Produk Ramah Lingkungan di Jakarta, Tesis, Universitas Indonesia, Jakarta.

Putra, INNA. 2007. Analisis Sensitifitas Saham Pada Perusahaan Property dan Real Estate yang Terdaftar di Bursa Efek Jakarta, ORYZA, Vol. 6, No. 2, 252-268

Putra, INNA. 2013. Perbedaan Profitabilitas Dan Tingkat Pengawasan Sebelum Dan Sesudah Merger Pada Bank Perkreditan Rakyat, Jurnal Keuangan dan Perbankan, Vol.17, No.2, 302-309

Riduwan. 2011. Dasar-Dasar Statistika. Bandung: Alfabeta.

Sari, CA. 2015. Perilaku Berbelanja On-line di Kalangan Mahasiswi Antropologi Universitas Airlangga, AntroUnairDotNet, Vol. IV, No.2, 205-216.

Sumarwan, Ujang. 2002. Perilaku Konsumen (Teori dan Penerapannya dalam Pemasaran). Ghalia Indonesia: Jakarta

Yamin, S. dan Kurniawan, H. 2009. SPSS Complete. Teknik Analisis Statistik Terlengkap dengan Software SPSS. Jakarta: Salemba Infotek.

Zaltman, $G$ and Wallendorf, M 1971. Consumer Behavior : Basic Findings and Management Implications. The United States of America : By John Willey and Sons Inc. 